\title{
PANORAMA DA EDUCAÇÃO PROFISSIONAL NO BRASIL
}

Semana Online Científica de Educação, 1a edição, de 25/10/2021 a 27/10/2021 ISBN dos Anais: 978-65-81152-18-5

\section{SILVA; Luênia Kaline Tavares da ${ }^{1}$}

\section{RESUMO}

A referência bibliográfica consultada para a discussão na Unidade I, de autoria de Ramos (2014), intitulado História e Política da Educação Profissional (EP), remete-se a uma contextualização histórica, política, econômica e social do desenvolvimento da EP no Brasil. As características e as finalidades da EP relacionadas aos seus marcos históricos são discutidas nos capítulos I, II e III do livro, com menção as análises sociais e políticas de Florestan Fernandes. Nessa conjuntura analítica, discute-se as principais mudanças ocorridas na educação secundária e no ensino médio no século XX, com destaque para a EP a partir da década de 1930, relacionando às leis educacionais vigentes naquele período. Nota-se a construção histórica da EP, com destaque para as ações dos últimos 20 anos, insere-se uma concepção democrática e integradora à política pública de educação tecnológica e profissional com as seguintes características: a) totalidade do sistema público que atua na EP; b) metas físicas e financeiras claras; c) documento básico que dispõe sobre princípios e diretrizes fundamentais para as ações políticas e pedagógicas. Ramos (2014), no Capítulo IV, disserta sobre "Conceitos para a construção de uma concepção de educação profissional comprometida com a formação humana". Neste capítulo, a autora apresenta alguns conceitos importantes para o entendimento da concepção da educação profissional comprometida com a formação humana. Após a leitura do Livro de autoria de Ramos (2014), intitulado História e Política da Educação Profissional (EP), compreende-se sobre a origem, reviravoltas, formulações sociopolíticas e contextualização histórica e social para que a EP fosse institucionalizada e reconhecida como modalidade de ensino e política pública educacional aos brasileiros menos favorecidos. Além disso, depreende-se das características e finalidades da EP relacionadas aos seus marcos históricos, segundo as análises sociais e políticas de Florestan Fernandes.

PALAVRAS-ChaVe: Políticas Públicas, Ensino Técnico Integrado, Trabalho, Prática Profissional 